\title{
Targeting cholesterol synthesis increases chemoimmuno-sensitivity in chronic lymphocytic leukemia cells
}

Indira Benakanakere ${ }^{1}$, Tyler Johnson ${ }^{1}$, Richard Sleightholm¹', Virgilio Villeda', Monika Arya', Ravi Bobba', Carl Freter ${ }^{1,2,3^{*}}$ and Chunfa Huang ${ }^{1,2,3^{*}}$

\begin{abstract}
Background: Cholesterol plays an important role in cancer development, drug resistance and chemoimmuno-sensitivity. Statins, cholesterol lowering drugs, can induce apoptosis, but also negatively interfere with CD-20 and rituximab-mediated activity. Our goal is to identify the alternative targets that could reduce cholesterol levels but do not interfere with CD-20 in chemo immunotherapy of chronic lymphocytic leukemia (CLL).

Methods: MEC-2 cells, a CLL cell line, and the peripheral blood mononuclear cells (PBMCs) from CLL patients were treated with cholesterol lowering agents, and analyzed the effect of these agents on cholesterol levels, CD-20 expression and distribution, and cell viability in the presence or absence of fludarabine, rituximab or their combinations.

Results: We found that MEC-2 cells treated with cholesterol lowering agents (BIBB-515, YM-53601 or TAK-475) reduced $20 \%$ of total cellular cholesterol levels, but also significantly promoted CD-20 surface expression. Furthermore, treatment of cells with fludarabine, rituximab or their combinations in the presence of BIBB-515, YM-53601 or TAK-475 enhanced MEC-2 cell chemoimmuno-sensitivity measured by cell viability. More importantly, these cholesterol lowering agents also significantly enhanced chemoimmuno-sensitivity of the PBMCs from CLL patients.

Conclusion: Our data demonstrate that BIBB-515, YM53601 and TAK-475 render chemoimmuno-therapy resistant MEC-2 cells sensitive to chemoimmuno-therapy and enhance CLL cell chemoimmuno-sensitivity without CD-20 epitope presentation or its downstream signaling. These results provide a novel strategy which could be applied to CLL treatment.
\end{abstract}

Keywords: Fludarabine, Rituximab, Cholesterol lowering agent, Chronic lymphocytic leukemia

\section{Background}

Chronic lymphocytic leukemia (CLL) is the most prevalent hematologic malignancy affecting Caucasian adults in Western countries. In the United States, about 15,000 new cases are diagnosed every year [1]. CLL is characterized by the accumulation of mature CD5, CD19, and CD23 B-lymphocytes in peripheral blood, bone marrow, lymph nodes and spleen [2]. The disease typically occurs in elderly patients (the average age at the time of diagnosis is

\footnotetext{
* Correspondence: freterc@slu.edu; chunfahuang@slu.edu

'Division of Hematology/Oncology, Department of Medicine, School of Medicine, University of Missouri, Columbia, MO 65212, USA

${ }^{2}$ Cancer Center, Saint Louis University, Saint Louis, MO 63110, USA

Full list of author information is available at the end of the article
}

around 72 years). Overall survival at 5 and 10 years ranges between $87 \%$ and $73 \%$ for low-risk patients and $29 \%$ and $16 \%$ for high risk patients [3]. CLL is widely heterogeneous in terms of progression, therapeutic response and outcome [4]. Approximately one-third of patients with CLL survive many years without requiring treatment, whereas others need multiple therapies early in the course of the disease [5]. Although the entire pathogenesis of CLL has not been elucidated, the widely held concept is that CLL is associated with a defective regulation of apoptosis, rather than uncontrolled cell proliferation [6].

Over the last three decades, chlorambucil has been the mainstay for the treatment of CLL; however, the complete 
response rate with chlorambucil is only about 10\% [7-9]. Purine analogues, particularly fludarabine, are effective agents to treat CLL, resulting in a higher complete response rate than chlorambucil or alkylating-based chemotherapies (20-30\% versus $10 \%)$ and a longer diseasefree interval; survival, however, is not prolonged [10]. Rituximab and alemtuzumab also result in a higher complete response rate than chlorambucil in chemonaïve patients [11,12]. Recent advances have now moved away from mono-therapy to combination including the chemoimmuno-therapy [13-17]. The combination of fludarabine, cyclophosphamide and rituximab treatment achieves complete responses in only $24 \%$ to $39 \%$ of patients $[15,16]$. Bendamustine, an alkylating agent, plus rituximab is the other commonly used regimen for CLL, achieving a response rate of $88 \%$ and a complete response rate of $26 \%$ [7]. In spite of some progress in therapy, CLL is still considered an incurable disease because most patients generally relapse and eventually develop drugresistance [4]. It is clear that new approaches to overcoming drug-resistance and potentiating the action of conventional therapy are urgently needed.

Cholesterol contributes to chemotherapy resistance in hepatocellular carcinoma [18], breast cancer cells [19] and prostate cancer cells [20]. Statins are inhibitors of 3hydroxy-3-methylglutaryl-coenzyme A (HMG-CoA) reductase which catalyzes the conversion of HMG-CoA into mevalonate, a rate-limiting step in the cholesterol biosynthetic pathway [21]. Statins are commonly prescribed medications that lower serum cholesterol and prevent cardiovascular diseases [22,23]. Beyond their cholesterollowering properties, statins have also been shown to induce apoptosis through extrinsic and intrinsic pathways [24-26], and exhibit important antitumor activity in colorectal cancer, breast cancer, lung cancer, prostate cancer, pancreatic cancer and many other malignancies [27-29]. Although statins can induce apoptosis of acute myelogenous leukemia cell lines [30] and CLL cells [31], they are unsuitable for CLL therapy because statins interfere with the detection of $\mathrm{CD}-20$ and impair rituximab-mediated complement-dependent cytotoxicity [32].

To avoid the negative interference of statins with CD-20 molecules and rituximab-mediated activity and to explore whether cholesterol levels contribute to chemoimmuno-sensitivity and drug-resistance of cancer cells, we chose several agents that inhibit squalene synthase or oxidosqualene cyclase, downstream steps in the cholesterol biosynthetic pathway, and used a CLL cell line (MEC-2) and the peripheral blood mononuclear cells (PBMCs) from CLL patients to investigate the effect of cholesterol lowering agents on the cholesterol levels, CD-20 expression and distribution, and cell viability with fludarabine, rituximab or their combinations. Our results indicate that the inhibitors of squalene synthase or oxidosqualene cyclase can significantly enhance CLL cell chemoimmuno-sensitivity.

\section{Results}

\section{Effect of chemoimmuno-therapeutic drugs in MEC-2 cell} viability and apoptosis

To investigate whether chemoimmuno-sensitivity of CLL cells could be altered, we chose MEC-2 cells, a fludarabine- and rituximab-insensitive CLL cell line. Cell viability, which indicates complement-dependent cytotoxicity that contributes significantly to clinical efficacy, was assessed by the MTT assay or Trypan blue staining after treatment. Figure 1A illustrates the dose effect of either fludarabine or rituximab on MEC-2 cell viability. At lower concentrations $(<10 \mu \mathrm{M}$ fludarabine or $10 \mu \mathrm{g} / \mathrm{ml}$ rituximab), fludarabine and rituximab have similar patterns in response to reduce cell viability. Higher concentrations demonstrate fludarabine cytotoxicity. Two different methods (MTT assay and Trypan blue staining) show similar results with exposure of MEC-2 cells to $10 \mu \mathrm{M}$ fludarabine, $10 \mu \mathrm{g} / \mathrm{ml}$ rituximab or their combinations for 3 days. They caused about $28 \%, 25 \%$ or $50 \%$ reduction of cell viability, respectively (Figure 1B). To further determine whether the reduction of cell viability in drug-treated cells is due to cell growth arrest or apoptosis, we analyzed DNA fragmentation as a result of the signature events of apoptosis. Figure 1C clearly shows that treatment of MEC-2 cells with the chemoimmuno-therapeutic drugs increases DNA fragmentation. These results demonstrate that chemo- or immunotherapeutic drugs induce MEC-2 apoptosis.

\section{Lovastatin enhances chemo-sensitivity in fludarabine-treated MEC-2 cells}

Earlier studies indicated that cholesterol biosynthesis (Figure 2) is mandatory for cellular growth and has been implicated in various aspects of tumor development and progression [33-35]. Certain classes of drugs, such as statins, inhibit mevalonate metabolism and exhibit growth inhibitory and pro-apoptotic properties as well as antitumor activity [27-29,36]. Next, we tested the effect of lovastatin on cholesterol metabolism and cell viability in chemoimmuno-therapeutic drug-treated MEC-2 cells. Figure 3A shows that incubation with $5 \mu \mathrm{M}$ lovastatin for 3 days reduced cellular cholesterol levels by $30 \%$. In cell treated with lovastatin, fludarabine and lovastatin plus fludarabine, cell viability was 75,80 , and $57 \%$ of control, respectively. However, lovastatin had little effect in the cells treated with rituximab alone (Figure 3B, middle panel). The results indicate that lovastatin may interfere with CD-20 and rituximab-mediated activity. One recent report showed that statins induce conformational changes of CD20 and impair rituximab-mediated complementdependent cytotoxicity [32], consistent with our findings. 


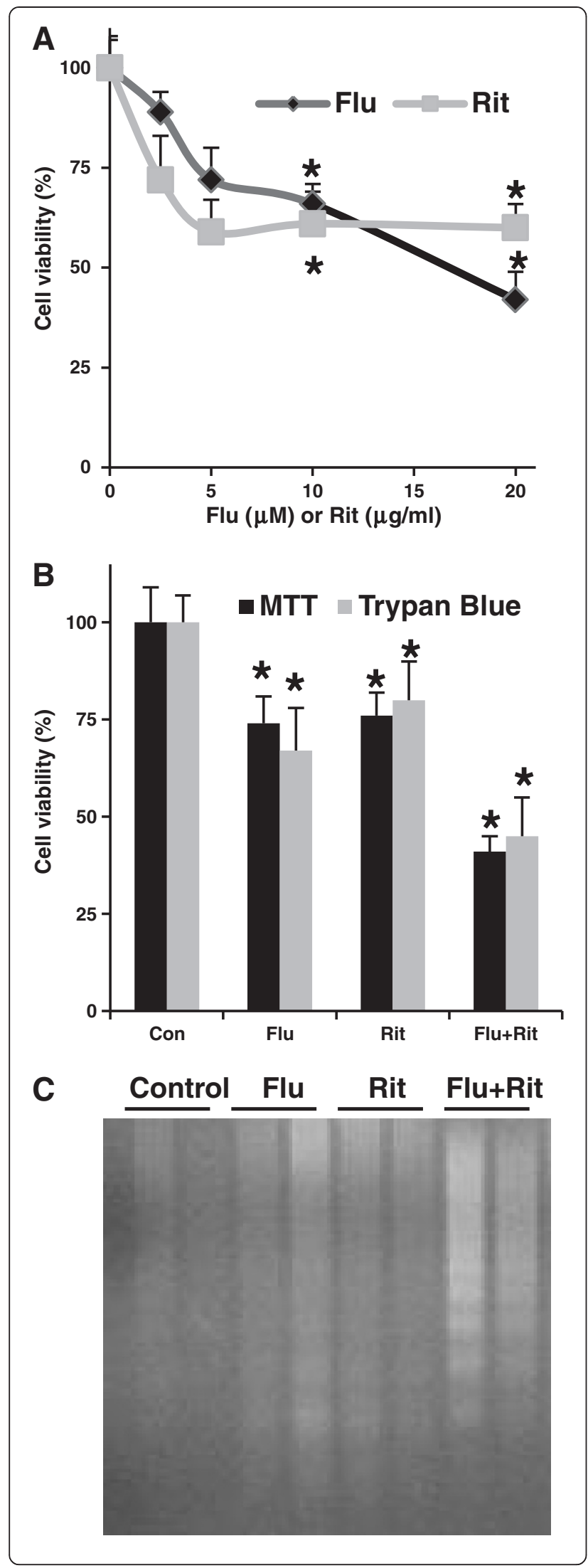

Figure 1 Effect of chemoimmuno-therapeutic drugs on MEC-2 cell viability and apoptosis. A) MEC-2 cells were treated with different concentration of fludarabine (Flu) or rituximab (Rit) $(n=16)$ for 3 days, and cell viability was analyzed by MTT assay. B) MEC-2 cells were treated with $10 \mu \mathrm{M}$ fludarabine, $10 \mu \mathrm{g} / \mathrm{ml}$ rituximab or their combinations for 3 days, and analyzed cell viability by either MTT assay $(n=16)$ or Trypan blue staining $(n=4)$ and DNA fragmentation (C). The DNA fragmentation represents three experiments performed with duplicate samples. The values of the treated groups were statistically different from the untreated control group. Con: control. ${ }^{*} P<0.05 .{ }^{* *} P<0.01$.

Effect of BIBB-515 and YM-53601 on MEC-2 cell chemoimmuno-sensitivity

To identify novel agents that not only block cholesterol biosynthesis and enhance chemoimmuno-sensitivity, but also avoid the interference with CD-20 and rituximabmediated activity, we targeted squalene synthase and oxidosqualene cyclase which are further downstream steps in cholesterol biosynthetic pathway (Figure 2). YM-53601 is a novel squalene synthase inhibitor that reduces plasma cholesterol and triglyceride levels in several animal species [37]. BIBB-515 is a selective inhibitor of 2,3-oxidosqualene cyclase and inhibits LDL production in both normolipemic and hyperlipemic hamsters [38]. Figure 4A shows that treatment of MEC-2 cells with either BIBB- 515 or YM-53601 for 3 days resulted in about 20\% decrease in total cellular cholesterol. By confocal microscopy, we also analyzed the expression and distribution of CD-20

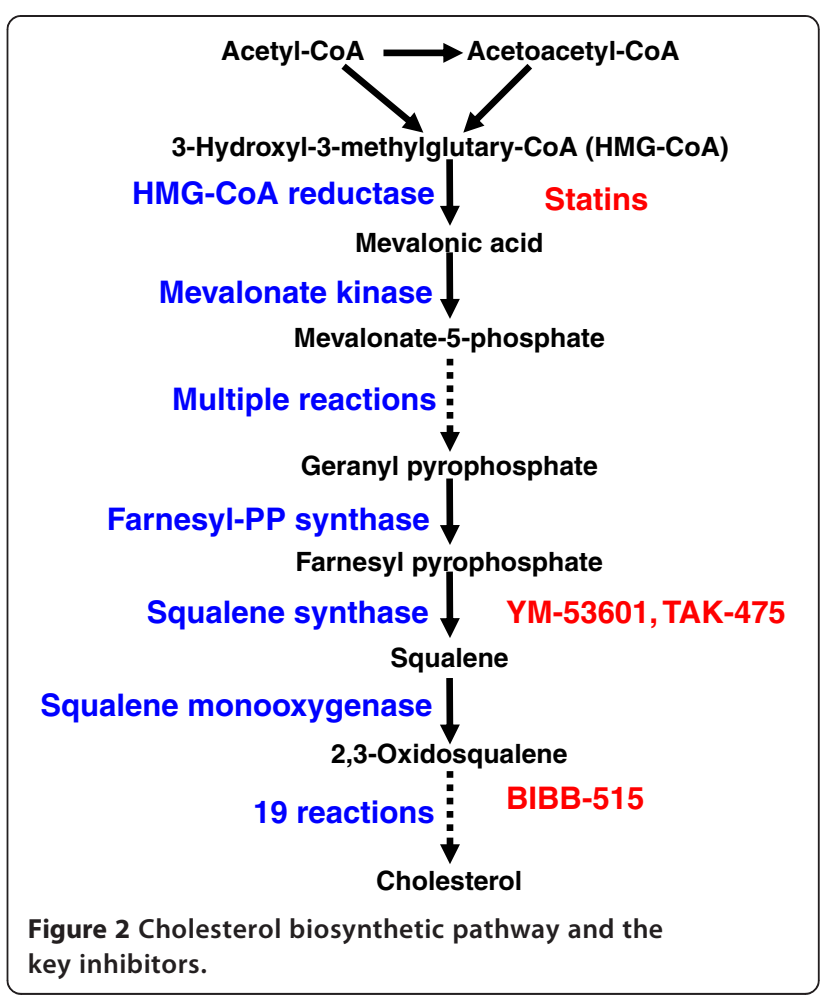




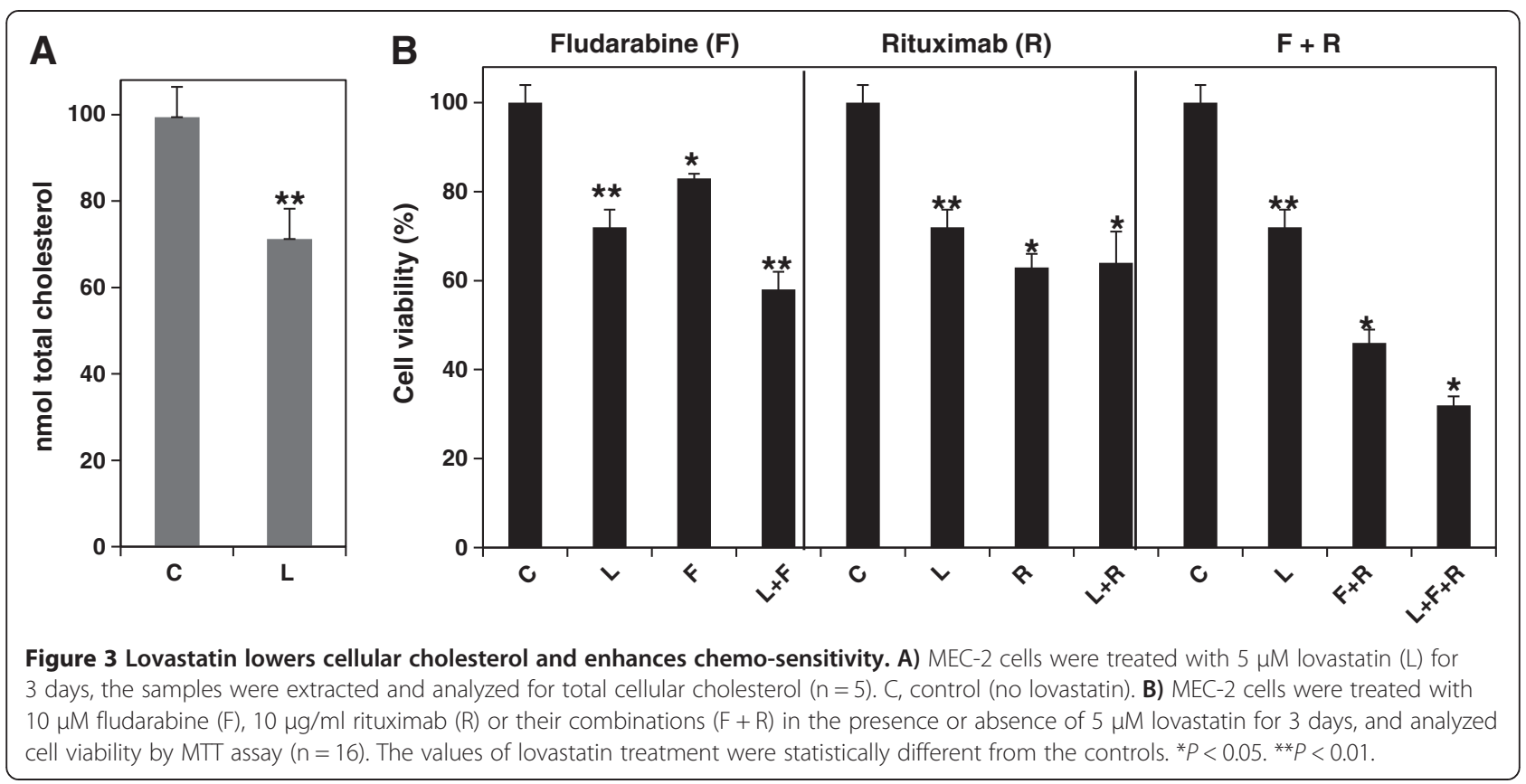

in the cells. As shown in Figure 4D, E, F and G, both BIBB-515 and YM-53601 slightly intensified CD-20 immunostaining, and dramatically increased CD-20 membrane association which would, in turn, lead to increased signaling through CD-20 to downstream pathways. Further studies indicated that either BIBB-515 or YM- 53601 enhanced chemoimmuno-sensitivity in the cells treated with fludarabine, rituximab or their combinations. Cell viability was reduced from $80 \%$ to $43 \%$ in BIBB- 515 (Figure 5A left) and from $75 \%$ to $61 \%$ in YM-53601
(Figure 5B left) with fludarabine treatment alone; from $70 \%$ to $59 \%$ in BIBB-515 (Figure 5A middle) and from $61 \%$ to $48 \%$ in YM53601 (Figure 5B middle) with rituximab treatment alone; and from $50 \%$ to $34 \%$ in BIBB-515 (Figure 5A right) and from $42 \%$ to $32 \%$ in YM-53601 (Figure 5B right) with their combination treatment. The data demonstrates that either BIBB-515 or YM-53601 can lower cellular cholesterol levels, up-regulate CD-20 membrane expression and enhance cell chemoimmunosensitivity.

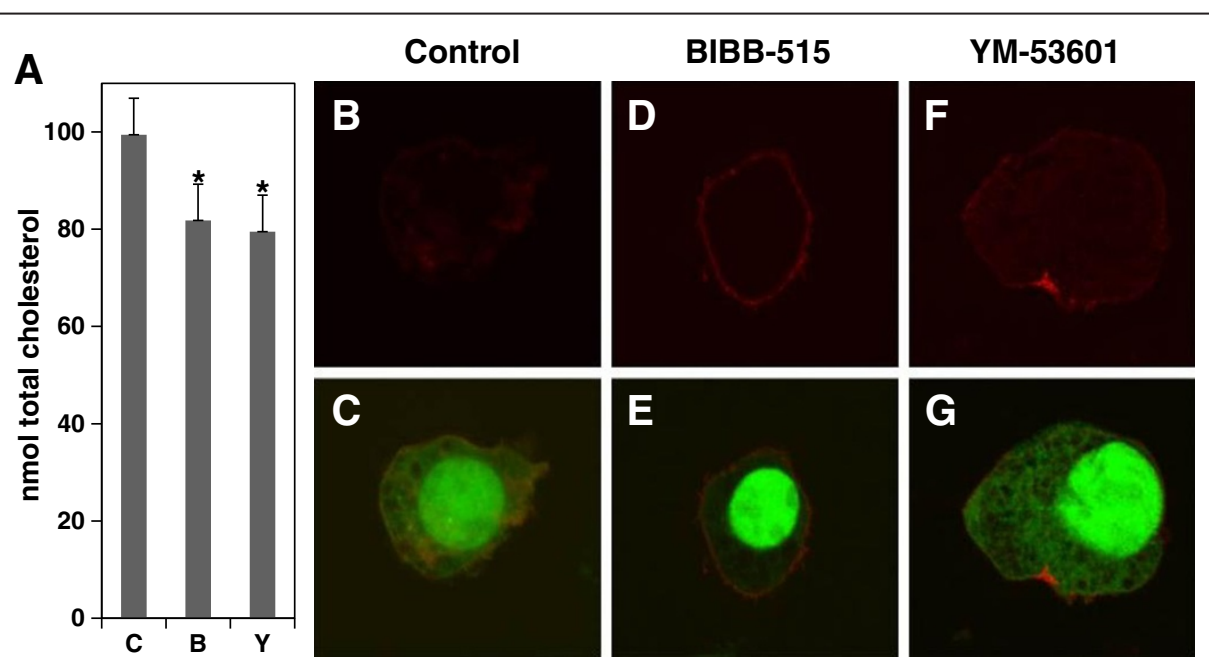

Figure 4 The influence of BIBB-515 and YM-53601 on cholesterol levels and CD20 expression in MEC-2 cells. MEC-2 cells were treated with $10 \mu \mathrm{M}$ either BIBB-515 (B) or YM-53601 (Y) for 3 days. A) The cells were extracted and analyzed for total cellular cholesterol. The values of treated with BIBB-515 or YM-53601 samples were statistically different from the control (C, without BIBB-515 or YM-53601) $(n=5) .{ }^{*} P<0.05$. B-G) The cells were stained for 1 hour with anti-CD-20 APC antibody and cholera toxin-B FITC, and observed and photographed by confocal microscope. The results represent three experiments performed with duplicate samples. 

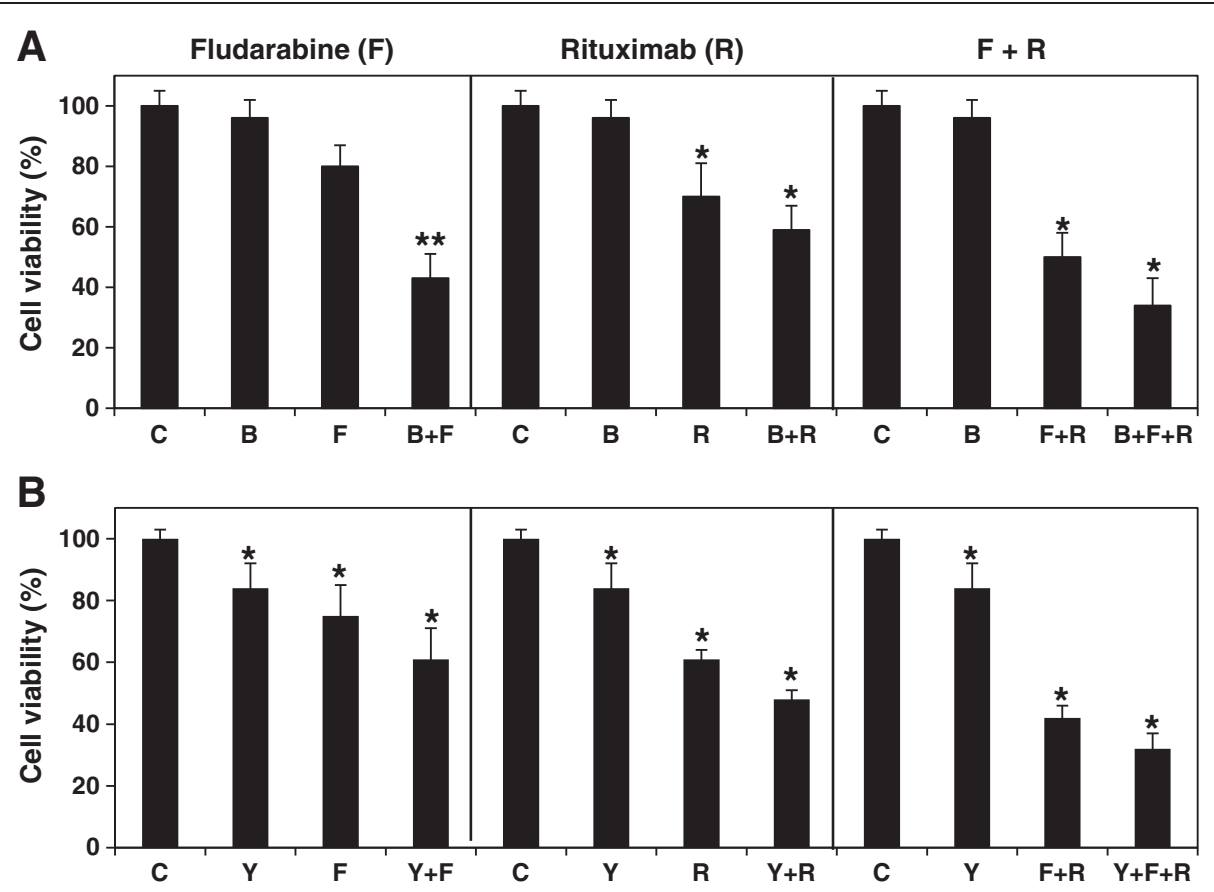

Figure 5 Effect of BIBB-515 and YM-53601 on chemoimmuno-sensitivity. MEC-2 cells were treated with $10 \mu \mathrm{M}$ fludarabine (F), $10 \mu \mathrm{g} / \mathrm{ml}$ rituximab ( $R$ ) or their combinations ( $F+R$ ) in the presence or absence of $10 \mu \mathrm{M}$ either BIBB-515 (B, panel A) or YM-53601 (Y, panel B) for 3 days, and analyzed cell viability by MTT assay. The values of treated with BIBB-515 or YM-53601 samples $(n=16)$ were statistically different from the controls (C). ${ }^{*} \mathrm{P}<0.05 .{ }^{*} \mathrm{P}<0.01$.

\section{TAK-475 enhances chemoimmuno-sensitivity in MEC-2} cells

TAK-475 (Lapaquistat) is another squalene synthase inhibitor that has been used as a cholesterol lowering drug in Phase III clinical trials in Europe and the United States [39]. To investigate the effect of TAK-475 on chemoimmuno-sensitivity, we firstly treated MEC-2 cells with $10 \mu \mathrm{M}$ TAK-475 for 3 days, and explored its effect on CD-20 expression and distribution. As shown in Figure 6, both CD-20 staining and membrane association are significantly increase in TAK-475 treated (Figure 6C and D) compared with those controls (Figure 6A and B). Next, we analyze the effect of TAK-475 on MEC- 2 cell chemoimmuno-sensitivity. As shown in Figure 6E, TAK-475 enhances chemoimmuno-sensitivity of fludarabine, rituximab and their combinations. With TAK-475, cell viability was decreased from $72 \%$ to $40 \%$ with fludarabine treatment alone, from $80 \%$ to $59 \%$ with rituximab treatment alone, and from $41 \%$ to $26 \%$ with their combination treatment.

\section{BIBB-515 and TAK-475 enhance chemoimmuno-sensitivity} in the PBMCs

Our results show that cholesterol lowering agents enhance chemoimmuno-sensitivity in MEC-2 cells. To investigate the potential cholesterol lowering agents for CLL chemoimmuno-therapy, we isolated the PBMCs from
CLL patients, treated the cells with $10 \mu \mathrm{M}$ fludarabine, $10 \mu \mathrm{g} / \mathrm{ml}$ rituximab, or their combinations in the presence or absence of either $10 \mu \mathrm{M}$ BIBB- 515 or TAK- 475 for 3 days, and determined cell viability by Trypan blue staining. With BIBB-515, cell viability was reduced from $75 \%$ to $63 \%$ with fludarabine alone, from $85 \%$ to $73 \%$ with rituximab alone, and from $76 \%$ to $57 \%$ with their combinations (Figure 7A). With TAK-475, cell viability was reduced from $66 \%$ to $58 \%$ with fludarabine alone, from $82 \%$ to $66 \%$ with rituximab alone, and from $64 \%$ to $49 \%$ with their combinations (Figure 7B). These results demonstrate that either BIBB-515 or TAK-475 enhances chemoimmuno-sensitivity in the PBMCs from CLL patients.

\section{Discussion}

Cholesterol plays an essential role in the stability and architecture of the plasma membrane and in the involvement of vesicle traffic and receptor signaling [40,41]. Emerging data from profiling of cancer tissues and animal models [42-44] as well as in vitro cancer cell lines [45] demonstrate that cholesterol is capable of regulating cell proliferation, migration, and signaling pathways in carcinogenesis, tumor development and chemotherapy resistance. Recognizing cholesterol as an important factor contributing to cancer development, many researchers focus on manipulating cholesterol metabolism as novel 

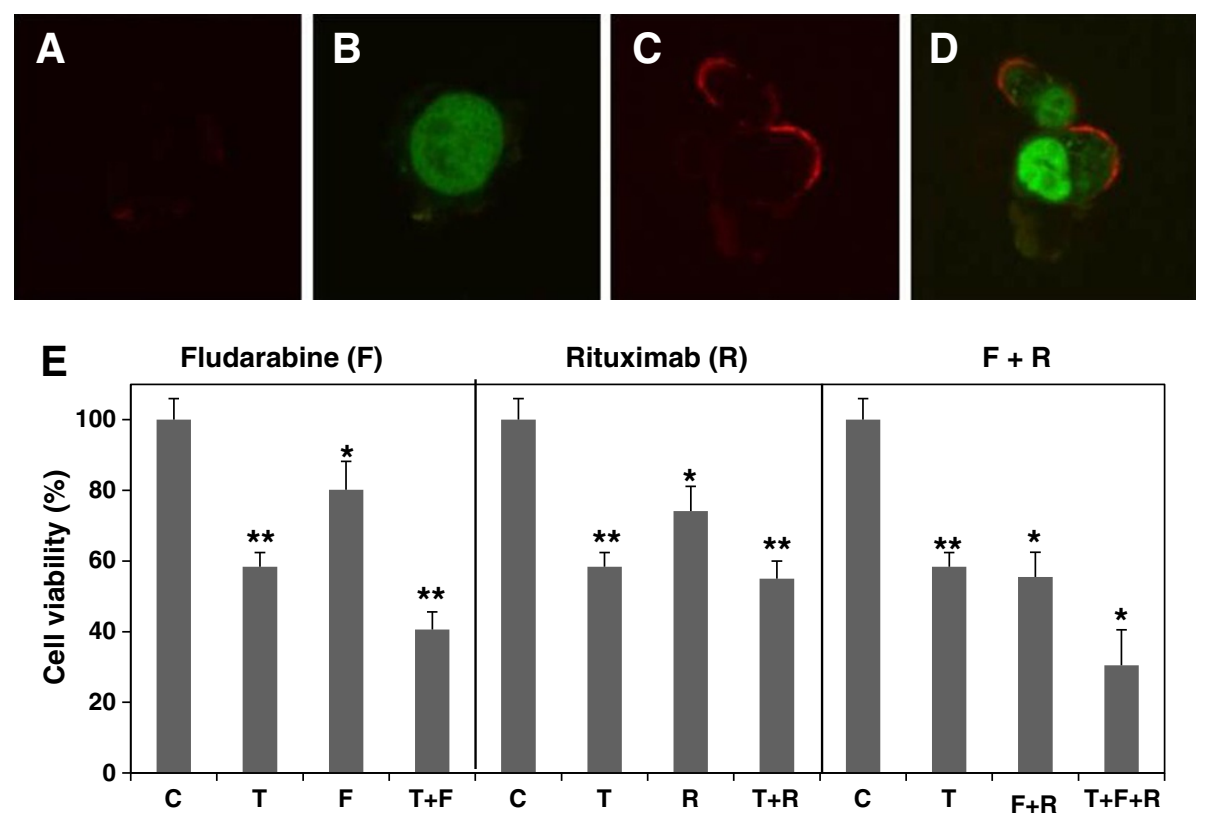

Figure 6 Effect of TAK-475 on CD-20 expression and chemoimmuno-sensitivity. MEC-2 cells were treated with $10 \mu \mathrm{M}$ TAK-475 (T) for 3 days, processed for double immunostaining, and photographed by confocal microscope (A-D). The results represent three experiments performed with duplicate samples. The cells were also treated with $10 \mu \mathrm{M}$ fludarabine $(\mathrm{F}), 10 \mu \mathrm{g} / \mathrm{ml}$ rituximab $(\mathrm{R})$ or their combinations $(\mathrm{F}+\mathrm{R})$ in the presence or absence of $10 \mu \mathrm{M}$ TAK-475 for 3 days, and then analyzed cell viability by MTT assay (E). The values of treated with TAK-475 samples $(n=16)$ were statistically different from the controls $(C) .{ }^{*} P<0.05$. ${ }^{*} P<0.01$.
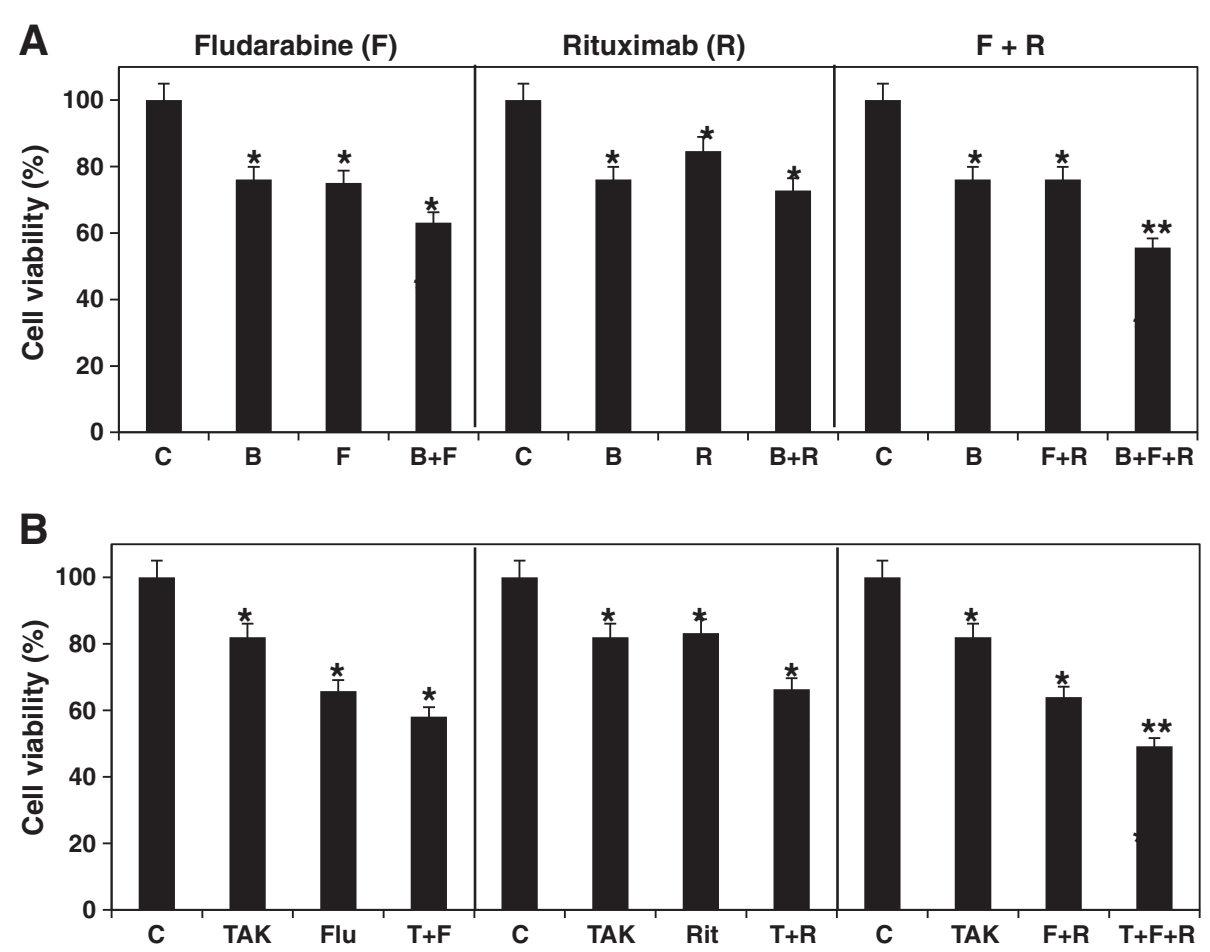

Figure 7 Effect of BIBB-515 and TAK-475 on chemoimmuno-sensitivity in the PBMCs from CLL patients. The PBMCs were treated with or without $10 \mu \mathrm{M}$ fludarabine $(F), 10 \mu \mathrm{g} / \mathrm{ml}$ rituximab $(R)$ or their combinations $(F+R)$ in the presence or absence of $10 \mu \mathrm{M}$ either BIBB-515 (B, panel A) or TAK-475 (T, panel B) for 3 days, and cell viability was determined by Trypan blue live-dead cell staining. The values of treated with BIBB-515 $(n=10)$ or TAK-475 $(n=6)$ samples were statistically different from the controls $(C) .{ }^{*} P<0.05 .{ }^{* * P}<0.01$. 
targets for cancer therapy [18-25]. Statins, cholesterol lowering agents, inhibit mevalonate metabolism and exhibit antitumor effects against various cancer cell lines [27-29]. Using lovastatin, we reported here that lowering cholesterol exhibited increased chemosensitivity in fludarabine-treated MEC-2 cells, but had no effect on immunotherapy in rituximab-treated cells (Figure 3). Earlier data from in vitro [32] and in vivo [46] also showed that statins do not influence clinical response and $\mathrm{B}$ cell depletion after rituximab treatment because statins induce conformational changes in CD-20 molecules and impair rituximab-mediated complement-dependent cytotoxicity.

CLL cell killing by rituximab requires cross linking of CD-20, which induces redistribution of CD-20 to lipid rafts. Lipid rafts are specialized microdomains of the plasma membrane that are enriched in sphingolipid and cholesterol, and play an important role in the initiation of many anticancer drug-induced signaling pathways and toxicological effects. Anticancer drugs are able to suppress cell growth and induce apoptosis of tumor cells through disrupting lipid raft integrity $[32,47]$. The redistribution of CD-20 may result in lipid raft disruption, activate or deactivate raft-associated proteins, such as death receptors and protein kinases in apoptotic pathway which are correlated with efficiency of complementdependent cytotoxicity and antibody-dependent cellmediated cytotoxicity. Rituximab and other anti-CD-20 antibodies are currently key drugs in CLL chemoimmunotherapy. Although statins have antitumor activity, they are clearly unsuitable for enhancement of chemoimmunosensitivity of lymphomas and leukemias.

To search for new agents that can lower cellular cholesterol, and do not negatively interfere with CD-20 and rituximab-mediated activity, we chose three compounds that can inhibit squalene synthase (YM-53601 and TAK475) or oxidosqualene cyclase (BIBB-515). These enzymes are further downstream steps in cholesterol biosynthetic pathway (Figure 2). By confocal microscopy, our results indicate that treatment of MEC-2 cells with YM-53601, BIBB-515 or TAK-475 did significantly up-regulate CD-20 surface expression and membrane-association (Figures 4 and 6). One recent study has shown that farnesyltransferase inhibitors may up-regulate CD-20 at mRNA and protein levels and improve anti-CD-20 monoclonal antibody-mediated activation of complement-dependent cytotoxicity [48]. Earlier reports demonstrated that cytokines (interleukin-4, granulocyte-macrophage colonystimulating factor, or interferon- $\alpha$ ) also increase CD-20 surface expression $[46,49]$. Taken together, our data and those results indicate that the agents inhibiting downstream steps of cholesterol biosynthesis and other cholesterolassociated pathways could positively regulate CD-20 expression and its antibody-mediated signaling.
Our observations indicate for the first time that BIBB515, YM-53601 and TAK-475 significantly inhibit their respective enzymes in the pathway of cholesterol biosynthesis to lower cellular cholesterol levels, and that targeting these enzymes could positively affect CD-20 distribution and its antibody-mediated activation in contrast to statins. Lowering cellular cholesterol levels with statins has been shown to induce apoptosis, [24-26] and have important antitumor activity in some malignancies [27-29]. Our experiments demonstrate that the cholesterol lowering agents BIBB-515, YM-53601 and TAK-475 render chemoimmuno-therapy resistant cells sensitive to chemoimmuno-therapy, and enhance cell chemoimmunosensitivity and apoptosis (Figures 5 and 6). These results validate the concept that cholesterol reduction using enzymatic inhibitors is different to the action of statins, probably due to different mechanism of activation of CD-20 dependent pathways.

We have also observed the effect of BIBB-515 and TAK-475 on chemoimmuno-sensitivity in the PBMCs from CLL patients. These cells from different patients show differences in response to three-day chemoimmunotherapeutic drug treatment. The PBMCs from two patients (total 14 patients) weakly responded to fludarabine, and three patients are very weak in response to rituximab; however, all of these patient cells showed a 5-30\% increase of chemoimmuno-sensitivity with cholesterol lowering agents. In these patients, two patients had undergone fludarabine treatment and one had undergone a round of chlorambucil and rituximab treatment. These PBMCs also show increased chemoimmuno-sensitivity with fludarabine, rituximab or their combinations in the presence of cholesterol lowering agents. Although cells treated with multiple drugs could cause pleiotropic effects, it is important that the combinations of BIBB-515, YM-53601 or TAK-475 and chemoimmuno-therapeutic drugs are synergistic effects. Our findings regarding the role of cholesterol on chemoimmuno-therapy along with recent reports in different types of cancer cells [18-29] highlight the relevance of cholesterol modulation in cancer therapy.

Decreased cell growth by lowering cellular cholesterol levels with statins in different cancer cells have been previously shown, we demonstrate that the mechanism of cholesterol modulation by other inhibitors is important because statins negatively affect CD-20 expression and antibody-mediated cell killing through CD-20. Our data demonstrate that BIBB-515, YM-52601 and TAK-475 acting at squalene synthase or oxidosqualene cyclase reduce cellular cholesterol levels, and inhibit cell growth leaving a CD-20 mediated pathway intact. Compensatory changes in membrane lipid composition as a result of treatment with these cholesterol synthesis inhibitors are an area we are investigating. Taken together, our results 
demonstrate that membrane lipid alteration in cancer cells is a novel and viable approach to both cancer therapeutics and reversal of chemoimmuno-therapy resistance.

\section{Material and methods Materials}

All chemicals were purchased from Sigma-Aldrich (St Louis, MO, USA) or Fisher Scientific (Pittsburgh, PA, USA) unless specified otherwise. Ficoll-Paque Plus was obtained from Amersham Biosciences (Piscataway, NJ, USA). The media for cell culture were purchased from GIBCO (Grand Island, NY, USA). The anti-CD-20 APC antibody was obtained from eBiosciences (San Diego, CA, USA). CellTiter $96^{\circ}$ Non-Radioactive Cell Proliferation Assay kit (MTT) was purchased from Promega (Madison, WI, USA). Fludarabine was obtained from Teva Parenteral Medicines, Inc (Irvine, CA, USA). Rituximab was obtained from Genentech (South San Francisco, CA, USA). BIBB-515 and YM-53601 were purchased from Cayman Chemical Company (Ann Arbor, MI, USA). TAK475 was obtained from Chemzon Scientific (Montreal, Quebec, Canada).

\section{Cell culture, PBMC isolation and cell treatment}

MEC-2 cells were cultured in DMEM/F-12 media with $10 \% \mathrm{FBS}$. Cells were grown at $37^{\circ} \mathrm{C}$ in $5 \% \mathrm{CO}_{2}$. Cholesterol lowering agents (BIBB-515, YM-53601 or TAK-475) were added to the cultures at $10 \mu \mathrm{M}$ final concentration in the presence or absence of fludarabine $(10 \mu \mathrm{M})$, rituximab $(10 \mu \mathrm{g} / \mathrm{ml})$ or their combinations for 3 days. Treated cells were used for analysis according to experimental design.

Blood was obtained from CLL patients as defined by NC196 criteria 28 [50] following receipt of written informed consent under an IRB protocol approved by the University of Missouri-Columbia. PBMCs were isolated from whole blood immediately following donation using Ficoll density gradient centrifugation. Isolated cells were treated with test compounds as experimental designed and incubated at $37^{\circ} \mathrm{C}$ and $5 \% \mathrm{CO}_{2}$ in RPMI-1640 media for 3 days. Cells were counted manually on a hemocytometer with Trypan blue solution before treatment, and at 1,2 , and 3 days after treatment to determine cell viability.

\section{Total cholesterol analysis}

Three million MEC-2 cells in the experiments were harvested, and $6 \mu \mathrm{l}$ of standard cholesterol $(1 \mathrm{mg} / \mathrm{ml}$ of chloroform) was added to the samples. Total cholesterol was extracted by the method of Bligh and Dyer [51]. The resulting organic lower phase was withdrawn and evaporated under a stream of $\mathrm{N}_{2}$. One milliliter of methanolic potassium hydroxide was added to the tubes, and the samples were heated at $80^{\circ} \mathrm{C}$ for 1 hour. The tubes were sonicated several times during saponification. After cooling down, $2 \mathrm{ml}$ of HPLC-grade water was added and the sterols were recovered by extracting the mixture 3 times with $3 \mathrm{ml}$ hexane. The hexane extracts were pooled and dried down under $\mathrm{N}_{2}$. After complete dry, the samples were re-dissolved in $70 \mu \mathrm{l}$ pyridine. The samples were derivatized by adding $30 \mu \mathrm{l} \mathrm{N}$-trimethylsilyl-Nmethyltrifluoroacetamide with trimethylchlorosilane and incubating at $50^{\circ} \mathrm{C}$ for 1 hour. The solvents were completely dried and re-dissolved in $75 \mu \mathrm{l}$ of chloroform. Gas chromatography mass spectrometry (GC/MS) analysis was performed at the Kansas Lipidomics Research Center on an Agilent 6890 N GC coupled to an Agilent 5975 N quadrupole mass selective detector. The data were collected and processed with Agilent Chemstation.

\section{Confocal microscopy}

MEC-2 cells were treated with various compounds for 3 days, washed in cold medium, and fixed with $4 \%$ paraformaldehyde in $100 \mathrm{mM}$ phosphate buffer on ice. The fixed cells were washed twice with 1\% BSA in PBS (BSA buffer). The cells were blocked for 15 minutes in 5\% mouse serum in PBS and washed with BSA buffer. The cells were stained for 1 hour with anti-CD-20 APC antibody and cholera toxin-B FITC. Wet-mount slides were prepared, and the samples were viewed by a Zeiss 510 META laser scanning confocal microscope and photographed by LSM 4.2 software.

\section{Cell viability assays}

MEC-2 cells were plated in 96-well assay plates at a concentration of 10,000 cells per well in $100 \mu$ l of culture medium with test compounds according to experimental designed. After adding the agents, the cells were cultured at $37^{\circ} \mathrm{C}$ for 3 days, and cell viability was determined using Promega's CellTiter $96^{\circ}$ Non-Radioactive Cell Proliferation Assay kit (MTT) according to the manufacturer's instructions. Absorbance at $570 \mathrm{~nm}$ was recorded using a Biotek Synergy H4 Hybrid Reader (Winooski, VT). MEC-2 cells and PBMCs were stained with Trypan blue solution, and dead and alive cells were counted after treatment to determine cell viability.

\section{Measurement of DNA fragmentation}

According to experimental designed, treatment of MEC-2 cells were harvested and centrifuged at $1,500 \mathrm{~g}$ for $2 \mathrm{~min}$, and the pellets were resuspended in $0.5 \mathrm{ml}$ of lysis buffer containing $5 \mathrm{mM}$ Tris- $\mathrm{HCl}, \mathrm{pH}$ 8.0, $20 \mathrm{mM}$ EDTA, and $0.5 \%$ Triton X-100 and placed on ice for $15 \mathrm{~min}$. The samples were then centrifuged at $12,000 \mathrm{~g}$ for $20 \mathrm{~min}$, and the supernatant containing DNA cleavage products in the same amount of cellular proteins was precipitated overnight using isopropyl alcohol. The samples were centrifuged at 24,446 g for $20 \mathrm{~min}$. Pellets were resuspended in Tris-EDTA buffer and digested with $0.2 \mathrm{mg} / \mathrm{ml}$ proteinase 
$\mathrm{K}$ and $1 \mathrm{mg} / \mathrm{ml} \mathrm{RNase} \mathrm{A}$ for $60 \mathrm{~min}$ at $48^{\circ} \mathrm{C}$. DNA fragments were separated on a $1.5 \%$ agarose gel, visualized with ethidium bromide, and photographed using the Bio-Rad image system.

\section{Data analysis}

Statistical analysis was done using Sigma plot 12. The difference in the mean values among treatment groups to the controls were analyzed by one way analysis of variance.

\section{Abbreviations}

CLL: Chronic lymphocytic leukemia; PBMC: Peripheral blood mononuclear cell; HMG-CoA: Hydroxy-3-methylglutaryl-coenzyme A.

\section{Competing interests}

The authors declare that they have no competing interests.

\section{Authors' contributions}

$\mathrm{IB}, \mathrm{CF}$, and $\mathrm{CH}$ conceived the experimental design. IB, $\mathrm{TJ}$, and $\mathrm{CH}$ performed the experiments and analyzed the data. W, RB, MA, and RS collected the patient samples and analysis. IB, CF and CH interpreted the data. CH and CF wrote the paper. All authors read and approved the final manuscript.

\section{Acknowledgements}

We thank the Kansas Lipidomics Research Center for Lipid analysis, Dr. Alexander Jurkevic at the Molecular Cytology Research Core Facility at the University of Missouri-Columbia for the help of confocal microscopy, and clinical trials office Lynn walker for patient bloods.

\section{Author details}

'Division of Hematology/Oncology, Department of Medicine, School of Medicine, University of Missouri, Columbia, MO 65212, USA. ${ }^{2}$ Cancer Center, Saint Louis University, Saint Louis, MO 63110, USA. ${ }^{3}$ Division of Hematology/ Oncology, Department of Internal Medicine School of Medicine, and Cancer Center, Saint Louis University, 3655 Vista Avenue, St. Louis, MO 63110-2539, USA.

Received: 28 July 2014 Accepted: 14 September 2014 Published: 26 September 2014

\section{References}

1. Siegel R, Naishadham D, Jemal A: Cancer statistics, 2013. CA Cancer J Clin 2013, 63:11-30.

2. Chiorazzi N, Hatzi K, Albesiano E: B-cell chronic lymphocytic leukemia, a clonal disease of $B$ lymphocytes with receptors that vary in specificity for (auto)antigens. Ann NY Acad Sci 2005, 1062:1-12.

3. Hallek M: Chronic lymphocytic leukemia: 2013 update on diagnosis, risk stratification and treatment. Am J Hematol 2013, 88:803-816.

4. Chiorazzi N, Rai KR, Ferrarini M: Chronic lymphocytic leukemia. N Engl J Med 2005, 352:804-815.

5. Zenz T, Mertens D, Kuppers R, Dohner H, Stilgenbauer S: From pathogenesis to treatment of chronic lymphocytic leukaemia. Nat Rev Cancer 2010, 10:37-50

6. Caligaris-Cappio F, Hamblin TJ: B-cell chronic lymphocytic leukemia: a bird of a different feather. J Clin Oncol 1999, 17:399-408.

7. Fischer K, Cramer P, Busch R, Böttcher S, Bahlo J, Schubert J, Pflüger KH, Schott S, Goede V, Isfort S, von Tresckow J, Fink AM, Bühler A, Winkler D, Kreuzer KA, Staib P, Ritgen M, Kneba M, Döhner H, Eichhorst BF, Hallek M, Stilgenbauer S, Wendtner CM: Bendamustine in combination with rituximab for previously untreated patients with chronic lymphocytic leukemia: a multicenter phase II trial of the German Chronic Lymphocytic Leukemia Study Group. J Clin Oncol 2012, 30:3209-3216.

8. Dighiero G, Maloum K, Desablens B, Cazin B, Navarro M, Leblay R, Cazin B, Navarro M, Leblay R, Leporrier M, Jaubert J, Lepeu G, Dreyfus B, Binet JL, Travade P: Chlorambucil in indolent chronic lymphocytic leukemia. N Engl J Med 1998, 21:1506-1514.
9. Robak T, Bloński JZ, Kasznicki M, Blasińska-Morawiec M, Krykowski E, Dmoszyńska A, Mrugala-Spiewak H, Skotnicki AB, Nowak W, Konopka L, Ceglarek B, Maj S, Dwilewicz-Trojaczek J, Hellmann A, Urasiński I, Zdziarska B, Kotlarek-Haus S, Potoczek S, Grieb P: Cladribine with prednisone versus chlorambucil with prednisone as first-line therapy in chronic lymphocytic leukemia: report of a prospective, randomized, multicenter trial. Blood 2000, 96:2723-2729.

10. Rai KR, Peterson BL, Appelbaum FR, Kolitz J, Elias L, Shepherd L, Hines J, Threatte GA, Larson RA, Cheson BD, Schiffer CA: Fludarabine compared with chlorambucil as primary therapy for chronic lymphocytic leukemia. N Engl J Med 2000, 343:1750-1757.

11. Hillmem P, Skotnicki AB, Robak T, Jaksic B, Dmoszynska A, Wu J, Sirard C, Mayer J: Alemtuzumab compared with chlorambucil as first-line therapy for chronic lymphocytic leukemia. J Clin Oncol 2007, 25:5616-5623.

12. Maloney DG, Grillo-López AJ, White CA, Bodkin D, Schilder RJ, Neidhart JA, Janakiraman N, Foon KA, Liles TM, Dallaire BK, Wey K, Royston I, Davis T, Levy R: IDEC-C2B8 (Rituximab) anti-CD20 monoclonal antibody therapy in patients with relapsed low-grade non-Hodgkin's lymphoma. Blood 1997, 90:2188-2195

13. Kay NE, Geyer SM, Call TG, Shanafelt TD, Zent CS, Jelinek DF, Tschumper R, Bone ND, Dewald GW, Lin TS, Heerema NA, Smith L, Grever MR, Byrd JC: Combination chemoimmunotherapy with pentostatin, cyclophosphamide, and rituximab shows significant clinical activity with low accompanying toxicity in previously untreated $B$ chronic lymphocytic leukemia. Blood 2007, 109:405-411.

14. Lamanna N, Kalaycio M, Maslak P, Jurcic JG, Heaney M, Brentjens R, Zelenetz AD, Horgan D, Gencarelli A, Panageas KS, Scheinberg DA, Weiss MA: Pentostatin, cyclophosphamide, and rituximab is an active, well-tolerated regimen for patients with previously treated chronic lymphocytic leukemia. J Clin Oncol 2006, 24:1575-1581.

15. Wierda W, O'Brien S, Wen S, Faderl S, Garcia-Manero G, Thomas D, Do KA, Cortes J, Koller C, Beran M, Ferrajoli A, Giles F, Lerner S, Albitar M, Kantarjian H, Keating M: Chemoimmunotherapy with fludarabine, cyclophosphamide, and rituximab for relapsed and refractory chronic lymphocytic leukemia. J Clin Oncol 2005, 23:4070-4078.

16. Tam CS, O'Brien S, Wierda W, Kantarjian H, Wen S, Do KA, Thomas DA, Cortes J, Lerner S, Keating MJ: Long-term results of the fludarabine, cyclophosphamide, and rituximab regimen as initial therapy of chronic lymphocytic leukemia. Blood 2008, 112:975-980

17. Elter T, Borchmann P, Schulz H, Reiser M, Trelle S, Schnell R, Jensen M, Staib P, Schinköthe T, Stützer H, Rech J, Gramatzki M, Aulitzky W, Hasan I, Josting A, Hallek $M$, Engert A: Fludarabine in combination with alemtuzumab is effective and feasible in patients with relapsed or refractory B-cell chronic lymphocytic leukemia: results of a phase II trial. J Clin Oncol 2005, 23:7024-7031.

18. Montero J, Morales A, Llacuna L, Lluis JM, Terrones O, Basañez G, Antonsson B, Prieto J, García-Ruiz C, Colell A, Fernández-Checa JC: Mitochondrial cholesterol contributes to chemotherapy resistance in hepatocellular carcinoma. Cancer Res 2008, 68:5246-5256.

19. Storch $\mathrm{CH}$, Ehehalt $\mathrm{R}$, Haefeli WE, Weiss J: Localization of the human breast cancer resistance protein (BCRP/ABCG2) in lipid rafts/caveolae and modulation of its activity by cholesterol in vitro. J Pharmacol Exp Ther 2007, 323:257-264.

20. Zhuang L, Kim J, Adam RM, Solomon KR, Freeman MR: Cholesterol targeting alters lipid raft composition and cell survival in prostate cancer cells and xenografts. J Clin Invest 2005, 115:959-968.

21. Alberts AW, Chen J, Kuron G, Hunt V, Huff J, Hoffman C, Rothrock J, Lopez M Joshua H, Harris E, Patchett A, Monaghan R, Currie S, Stapley E, Albers-Schonberg G, Hensens O, Hirshfield J: Mevinolin: a highly potent competitive inhibitor of hydroxymethylglutaryl-coenzyme A reductase and a cholesterol-lowering agent. Proc Natl Acad Sci U S A 1980, 77:3957-3961.

22. Bonetti PO, Lerman LO, Napoli C, Lerman A: Statin effects beyond lipid lowering-are they clinically relevant? Eur Heart J 2003, 24:225-248.

23. McKenney JM: New cholesterol guidelines, new treatment challenges. Pharmacotherapy 2002, 22:853-863.

24. Agarwal B, Bhendwal S, Halmos B, Moss SF, Ramey WG, Holt PR: Lovastatin augments apoptosis induced by chemotherapeutic agents in colon cancer cells. Clin Cancer Res 1999, 5:2223-2229.

25. Cho SJ, Kim JS, Kim JM, Lee JY, Jung HC, Song IS: Simvastatin induces apoptosis in human colon cancer cells and in tumor xenografts, and attenuates colitis-associated colon cancer in mice. Int J Cancer 2008, 123:951-957. 
26. Xiao H, Zhang Q, Lin Y, Reddy BS, Yang CS: Combination of atorvastatin and celecoxib synergistically induces cell cycle arrest and apoptosis in colon cancer cells. Int J Cancer 2008, 122:2115-2124.

27. Chan KK, Oza AM, Siu LL: The statins as anticancer agents. Clin Cancer Res 2003, 9:10-19.

28. Sassano A, Platanias LC: Statins in tumor suppression. Cancer Lett 2008, 260:11-19.

29. Bardou M, Barkun A, Martel M: Effect of statin therapy on colorectal cancer. Gut 2010, 59:1572-1585.

30. Xia Z, Tan MM, Wong WW, Dimitroulakos J, Minden MD, Penn LZ: Blocking protein geranylgeranylation is essential for lovastatin-induced apoptosis of human acute myeloid leukemia cells. Leukemia 2001, 15:1398-1407.

31. Chapman-Shimshoni D, Yuklea M, Radnay J, Shapiro H, Lishner M: Simvastatin induces apoptosis of B-CLL cells by activation of mitochondrial caspase 9. Exp Hematol 2003, 31:779-783.

32. Winiarska M, Bil J, Wilczek E, Wilczynski GM, Lekka M, Engelberts PJ, Mackus WJ, Gorska E, Bojarski L, Stoklosa T, Nowis D, Kurzaj Z, Makowski M, Glodkowska E, Issat T, Mrowka P, Lasek W, Dabrowska-Iwanicka A, Basak GW, Wasik M, Warzocha K, Sinski M, Gaciong Z, Jakobisiak M, Parren PW, Golab J: Statins impair antitumor effects of rituximab by inducing conformational changes of CD20. PLoS Med 2008, 5:e64.

33. Pelton K, Freeman MR, Solomon KR: Cholesterol and prostate cancer. Curr Opin Pharmacol 2012, 12:751-759.

34. Gorin A, Gabitova L, Astsaturov I: Regulation of cholesterol biosynthesis and cancer signaling. Curr Opin Pharmacol 2012, 12:710-716.

35. Danilo C, Frank PG: Cholesterol and breast cancer development. Curr Opin Pharmacol 2012, 12:677-682.

36. Thurnher M, Nussbaumer O, Gruenbacher G: Novel aspects of mevalonate pathway inhibitors as antitumor agents. Clin Cancer Res 2012, 18:3524-3531.

37. Ugawa T, Kakuta H, Moritani H, Matsuda K, Ishihara T, Yamaguchi M, Naganuma S, lizumi Y, Shikama H: YM-53601, a novel squalene synthase inhibitor, reduces plasma cholesterol and triglyceride levels in several animal species. Br J Pharmacol 2000, 131:63-70.

38. Eisele B, Budzinski R, Müller P, Maier R, Mark M: Effects of a novel 2,3-oxidosqualene cyclase inhibitor on cholesterol biosynthesis and lipid metabolism in vivo. J Lipid Res 1997, 38:564-575.

39. Stein EA, Bays H, O'Brien D, Pedicano J, Piper E, Spezzi A: Lapaquistat acetate: development of a squalene synthase inhibitor for the treatment of hypercholesterolemia. Circulation 2011, 123:1974-1985.

40. Simons K, Ikonen E: How cells handle cholesterol. Science 2000, 290:1721-1726.

41. Luu W, Sharpe $L$, Gelissen IC, Brown AJ: The role of signalling in cellular cholesterol homeostasis. IUBMB Life 2013, 65:675-684.

42. Krycer JR, Brown AJ: Cholesterol accumulation in prostate cancer: a classic observation from a modern perspective. Biochim Biophys Acta 1835, 2013:219-229.

43. Hilvo M, Denkert C, Lehtinen L, Muller B, Brockmoller S, Seppanen-Laakso T, Budczies J, Bucher E, Yetukuri L, Castillo S, Berg E, Nygren H, Sysi-Aho M, Griffin JL, Fiehn O, Loibl S, Richter-Ehrenstein C, Radke C, Hyötyläinen T, Kallioniemi O, Ijin K, Oresic M: Novel theranostic opportunities offered by characterization of altered membrane lipid metabolism in breast cancer progression. Cancer Res 2011, 71:3236-3245.

44. Hirsch HA, lliopoulos D, Joshi A, Zhang Y, Jaeger SA, Bulyk M, Tsichlis PN, Shirley Liu X, Struhl K: A transcriptional signature and common gene networks link cancer with lipid metabolism and diverse human diseases. Cancer Cell 2010, 17:348-361.

45. Das S, Fernandez Matilla M, Dass S, Buch MH, Rawstron AC, Vital EM, Emery $P$ : Statins do not influence clinical response and B cell depletion after rituximab treatment in rheumatoid arthritis. Ann Rheum Dis 2013, 72:463-464

46. Sivaraman $S$, Venugopal $P$, Ranganathan $R$, Deshpande CG, Huang X, Jajeh A, Gregory SA, O'Brien T, Preisler HD: Effect of interferon-alpha on CD20 antigen expression of B-cell chronic lymphocytic leukemia. Cytokines Cell Mol Ther 2000, 6:81-87.

47. Winiarska M, Nowis D, Bil J, Glodkowska-Mrowka E, Muchowicz A, Wanczyk M, Bojarczuk K, Dwojak M, Firczuk M, Wilczek E, Wachowska M, Roszczenko K, Miaczynska M, Chlebowska J, Basak GW, Golab J: Prenyltransferases regulate $C D 20$ protein levels and influence anti-CD20 monoclonal antibody-mediated activation of complement-dependent cytotoxicity. J Biol Chem 2012, 287:31983-31993.
48. Venugopal P, Sivaraman S, Huang XK, Nayini J, Gregory SA, Preisler HD: Effects of cytokines on CD20 antigen expression on tumor cells from patients with chronic lymphocytic leukemia. Leuk Res 2000, 24:411-415.

49. Ohmachi K, Niitsu N, Uchida T, Kim SJ, Ando K, Takahashi N, Takahashi N, Uike N, Eom HS, Chae YS, Terauchi T, Tateishi U, Tatsumi M, Kim WS, Tobinai K, Suh C, Ogura M: Multicenter phase II study of bendamustine plus rituximab in patients with relapsed or refractory diffuse large B-cell lymphoma. J Clin Oncol 2013, 31:2103-2109.

50. Cheson BD, Bennett JM, Grever M, Kay N, Keating MJ, O'Brien S, Rai KR: National Cancer Institute-sponsored Working Group guidelines for chronic lymphocytic leukemia: revised guidelines for diagnosis and treatment. Blood 1996, 87:4990-4997.

51. Bligh EG, Dyer WJ: A rapid method of total lipid extraction and purification. Can J Biochem Physiol 1959, 37:911-917.

doi:10.1186/2162-3619-3-24

Cite this article as: Benakanakere et al.: Targeting cholesterol synthesis increases chemoimmuno-sensitivity in chronic lymphocytic leukemia cells. Experimental Hematology \& Oncology 2014 3:24

\section{Submit your next manuscript to BioMed Central and take full advantage of:}

- Convenient online submission

- Thorough peer review

- No space constraints or color figure charges

- Immediate publication on acceptance

- Inclusion in PubMed, CAS, Scopus and Google Scholar

- Research which is freely available for redistribution 